\title{
Mozart Music Increases The Number Of Glial Cells Compared To Indonesia Pop And Religious Music
}

\author{
1Pipit Sri Estuning Rahayu, ${ }^{2}$ Hermanto, ${ }^{3}$ Widjiati \\ ${ }^{1}$ Ilmu Kesehatan Reproduksi Fakultas Kedokteran Universitas Airlangga \\ ${ }^{2}$ Departemen Obstetri dan Ginekologi Fakultas Kedokteran Universitas Airlangga - RSUD \\ Dr. Soetomo Surabaya \\ ${ }^{3}$ Departemen Anatomi Veteriner Fakultas Kedokteran Hewan Universitas Airlangga
}

Email : pipits0228@gmail.com

Received : Nov 19th 2019 . Revised : Nov 27th 2019 . Published : Dec $23^{\text {th }} 2019$

DOI : https://doi.org/10.22219/sm.Vol15.SMUMM2.10265

\begin{abstract}
Music stimulation is an important component for prenatal fetal development. Both pop and religious music are easy to listen and widely accepted in Indonesia. This study was to analyze the effect of Mozart, pop, and religious music exposure during pregnancy to the number of glial cells in the brain of Rattus norvegicus offspring. The samples were divided into three groups based on the exposure for each group, namely Mozart, pop, and religious music, duration of 60 minutes with $65 \mathrm{~dB}$ intensity, initiated on the $10^{\text {th }}$ day of pregnancy for 9 days in the soundproof chamber. Three brains of the offsprings were dissected and prepared for Hematoxylin-Eosin staining counted on 5 fields of view and 400 magnification strength.Different glial cells number of Rattus norvegicus brain between groups were observed. Mozart music $(28,29)$ showed a highest mean and pop music $(18,67)$ showed the lowest mean. Significant difference of the number of brain glial cells between Mozart music compared to pop and religious music groups were observed, with $\mathrm{p}$ value $<0,005$. The number of brain glial cells of Rattus norvegicus offsprings in the Mozart group were significantly higher than those in pop and religious groups.
\end{abstract}

Keywords: Mozart, pop, religious, glial.

Copyright (C) 2019, First Author et al This is an open access article under the CC-BY-SA license

\section{INTRODUCTION}

Human resources development brought various aspect, both in social or economic value of the country. Human resouces development index of a certain country could be reflected through Human Development Index (HDI) rank. Indonesia was ranked 116 th of 189 countries in 2017 (UNDP, 2018). To improve the index, Indonesia have to prepare for the next generation that graced with intelligence and quality. Intelligence as a biopsychosocial potential associated with innervation, and is known from the number of neuron, glial, dendrites, synapses, and glial to neuron ratio (Hermanto, 2013). 
An excellent communication and collaboration between neuron and glial generates a proper brain function (Hill, 2015). Glial cells play a major and irreplaceable function and contribute for half of the brain volume. Glial cells act as synapse formation controller, which plays a role in nerve activity (Houzel, 2014). Increased glial cells number is an indicator of a proper synapse function and may be associated with human intelligence (Verkhratsky, 2010). Initial glial cells establishment were started as early as the $28^{\text {th }}$ day of conception (Hepper, 2007). Glial cells undergo proliferation, migration, myelinisation, apoptosis, prunning, and synaptogenesis in the uterus. Glial cells proliferation continues to postnatal period (Hill, 2015).

An adequate stimulation is a factor that affect fetal intelligence potential, in addition to nutrition and genetic factors. Experts proposed that prenatal sound is a fetal growth factor in prenatal period (Hermanto, 2013). Fetal begin to listen actively at 24 weeks of gestation (Whitwell, 2009). Music stimulation is an important component for prenatal fetal development (Sari, 2005). Music stimulation received by the fetus will stimulate auditory function and subsequently calcium is delivered by the nervous system to the brain (Sanyal et al., 2013). In the brain, calcium signal is processed and procude proteins that play a role in glial cells development (Chaudhury et al., 2013).

Mozart evidently promote optimal cells growth (Hermanto, 2013). Mozart music composed of a certain tine, rhythm, intensity and duration composition that play a major role in prenatal stimulation (Xing et al., 2015). Mozart music has some superior features, it beats 60-80 times per minute, $8000 \mathrm{~Hz}$ frequency, and composed mainly with major tone (Hermanto, 2013). Pop and religious music are both preferred by Indonesians. Indonesian survey scale results on 2018 indicte that $31,3 \%$ of Indonesians preferred for pop music, and religious music was preferred by $1,2 \%$ of the participants. A close and frequently heard music will affect a certain paart of the brain easier than a novel music. Mozart music stimulation has been studied extensively, however, it bear a different features with pop and religious music that preferred by most of Indonesians and have not been studied. Therefore the objective of this study was to determine the difference of brain glial cells number of Rattus norvegicus offspring that exposed to Mozart and Indonesia pop and religious music during pregnancy.

\section{METHODS}

This study was an exerimental analytical study employed randomized post test only control group as a study design. The study was conducted at Veterinary Medicine Faculty of Airlangga University between June to October 2009. Model organism Rattus norvegicus was employedas a substitute for pregnant human model for more invasive study due to ethical issue. Samples were female Sprague Dowles strain of Rattus novegicus aged 2 - 3 months, initial weight of 120 - 130 gram, pregnant, inclusion criteria including: never been used as a model organism, and had never given birth. 
The samples were divided into three groups randomly, impregnation was achived by 10 IU PMSG injection, 48 hours later 10 IU hCG injection then administered, and mated with monomating technique. Pregnancy was diagnosed by the presence of copulatory plug that covered the cervix to the vulva. On the $10^{\text {th }}$ day of the pregnancy, each groups were exposed with Mozart, pop, and religious music in 60 minutes duration, $65 \mathrm{~dB}$ intensity for 9 days in a soundproof chamber. Mozart music is composed by W.A. Mozart, consist of 14 songs in a spesific order. Pop music employed in this study was Rossa pop music of Love, Live, and Music album in 2014 consist of 10 songs with a certain order. Religious music employed was Sabyan religious music of Special Religious Album in 2018 consist of 5 songs in a certain order.

On the $19^{\text {th }}$ day of pregnancy, sample organisms were sacrificed, three offsprings of each subjects with the heaviest, moderate, and lightest weight were chosen, the brain was dissected and prepared for histochemistry, glial cells were counted by Hematoxylin-Eosin staining per 5 fields of view per sample with 400 magnification strength. Statistical analysis performed by Kruskal-Wallis test subequently processed with Mann Whitney difference test.

\section{RESULTS AND DISCUSSION}

This study was conducted to compare the differences of glial cells in the brain of Rattus norvegicus offsprings btween those that exposed with Mozart, pop, and religious music during pregnancy. Music stimulation during pregnancy was reported increase fetal brain development, increase spatial capability of the rat offspring, and promote rapid motoric capability development. Prenatal music exposure increase hippocampus neuron development process and increase spatial capability of the rat offspring. Conversely, the exposure of prenatal noise may inhibits growth, decrease hippocampus neurogenesis process and interfere rat offspring spatial capability (Kim dkk, 2006).

Table 1.1 Means and deviation standards, normality test glial cells number of Rattus norvegicus offspring brain

\begin{tabular}{lcc}
\hline \multicolumn{1}{c}{ Group } & Mean \pm SD & Shapiro wilk test \\
\hline Mozart & $28,29 \pm 5,10$ & 0,012 \\
\hline Pop & $18,67 \pm 6,05$ & $0,096^{*}$ \\
\hline Religious & $25,29 \pm 4,23$ & $0,066^{*}$ \\
\hline${ }^{*} \mathrm{p}>0,05=$ normal and homogen data spread & &
\end{tabular}

Table 1.1 showed the mean glial cells in Mozart group $(28,29)$ was the highest while pop music group $(18,67)$ with the lowest glial cells. Previous study stated that Mozart music exposure during pregnancy could increase the number of brain cells of rat offspring compared with groups that exposed with Gamelan, Dangdut, or without music exposure (Hermanto, 2013). 
Table 1.2 Kruskal Wallis test, Mann Whitney test, and Independent T-Test results on the brain glial cells number

\begin{tabular}{ccccc}
\hline Group & \multicolumn{2}{c}{$\boldsymbol{P}_{\text {value }}$} & \\
\cline { 2 - 4 } & $\begin{array}{c}\text { Mozart } \\
\text { music }\end{array}$ & Pop music & $\begin{array}{c}\text { Religious } \\
\text { music }\end{array}$ & $\begin{array}{c}\text { Kruskal- } \\
\text { Wallis test }\end{array}$ \\
\hline Musik Mozart & - & $0,000^{\mathrm{a}}$ & $0,09^{\mathrm{a}}$ & \multirow{2}{*}{0,000} \\
\hline Musik pop & $0,000^{\mathrm{a}}$ & - & $0,002^{\mathrm{b}}$ & \\
\hline Musik religi & $0,029^{\mathrm{a}}$ & $0,002^{\mathrm{b}}$ & - & \\
\hline
\end{tabular}

Significance $\mathrm{p}<0,05=$ significant difference

a : tested with Mann-Whitney test

$\mathrm{b}:$ tested with Independent T-test

Glial Cells Number of Mozart Music was Higher than Pop and Religious Music

The number of Rattus norvegicus offspring glial cells exposed with Mozart, pop, and religious music were significantly different. The study results were in accordance with Sanyal et al., (2013) that observed increased glial cells number due to music stimulation. Glial cells act as synapses formation controller, act during neuronal activity, including sensoric stimulation by increasing intracellular calcium signal. In addition, glial cells also provide lactate as an energy source to neuron and support energy for axon (Houzel, 2014). Connectivity between neuronal and glial cells includes analyzing, processing, storing and employing the received information in cognitive function. Proper information process in neuronal and glial cells connectivity showed brain function and intelligence (Verkhratsky, 2010).

Mozart K265 music has been proven to increase the duration and number of acceleration and the number of fetal movement (Hermanto dkk, 2004). The study of Dr. Alfred Tomatis and Don Campbell indicates that musics composed by Wolfgang Amadeus Mozart provide the ost positive effect on fetals, infants, adn children development. Mozart music has rhythm, melody, and high frequency and can stimulate the creative and motivational areas of the brain so as to calm its listeners, improve concentration, memory, and spatial perception (Campbell, 2003).

Table 1.3 Analysis resuls of Mozart, pop, and religious music

\begin{tabular}{lccc}
\hline \multicolumn{1}{c}{ Music } & Frequency & Rhytm & Mayor/Minor \\
\hline Mozart & $7045 \mathrm{~Hz}$ & $60-80 \mathrm{x} /$ minute & Mainly major \\
\hline Pop & $12764 \mathrm{~Hz}$ & $54-132 \mathrm{x} /$ minute & Mainly minor $(60 \%)$ \\
\hline Religious & $10496 \mathrm{~Hz}$ & $56-90 \mathrm{x} /$ minute & Mainly major $(60 \%)$ \\
\hline
\end{tabular}

Music analysis on Table 1.3 was performed by cubase 5 software showed that Mozart music has the lowest frequency and rhythm compared to two other musics and dominated with major tone. Mozart music is music genre with $5000-8000 \mathrm{~Hz}$ frequency or mainly consist of major notes. Mozart music frequency is the range of frequencies that can be heard and received by the human ear well. The difference in frequency between Mozart, pop, and religious music will be captured differently by cochlear tonocopy, leads to the different brain response. The sensitivity of basilar membrane at the base of chinchillacocblea obtained sensitivity at the $8000 \mathrm{~Hz}$ frequency which is beneficial to fill brain cells (Hermanto, 2017). 
Another element possessed by Mozart music is rhythm. Rhythm is the number of beats per minute. Rhythm Mozart music is approximately $60-80$ beats per minute. The $60-80$ beats per minute beats rhythm allow the best leverage due to its conformity with the mother's heart beat (Hermanto, 2013). This state of brain enters the alpha waves, the waves that occur when someone experience relaxation (Mustajib, 2010). Mozart music stimulation in rat allow a more excellent results in term of intelligence compared to noise stimulation. The assessment of rat brain showed increased BDNF, CREB, and synapsin -1 expression of the rat that exposed with Mozart music (Singer, 2004).

The standard order of Mozart music employed in this study has been proved to generate the lowest apoptosis index in the neuron cells of rat offspring. The positive effect of the standard order Mozart music originated from altered protein number and neuron degeneration (Ismudi dkk, 2007). Sound waves stimulation received by the ear and converted into electrical pulses subsequently passed on to the auditory cortex through auditory nerves when the ear is fully formed. Therefore, music stimulation will be effective after the formation and functioning of the ear and the formation of syanpses on the $20-24$ weeks of gestation or equivalent to the $10^{\text {th }}$ day of gestation of the rat (Ernawati dkk, 2008).

Prenatal music stimulation produce increased neurogenesis process through decrease brain cells death (Sanyal et al., 2013). Auditory stimulation is one of the external stimulation for perinatal stimulation. Optimal sound level in an adequate duration may be act as ausitory stimulus to generate varius brain function (Chaudhury, 2013). Kim et al., (2006) conducted a study on a model organism with noise and music exposure during prenatal period. Model organism exposed with noise leads to growth disorder, decreased hippocampus neurogenesis and spatial capabilit disorder. Whereas, music exposed model organism showed increased neurogenesis and higher spatial capability. These demonstrate that prenatal environment affect cognitive function and brain development (Kim, 2006).

\section{CONCLUSION}

The number of glial cells of the offspring of Ramus norvegicus brain in the Mozart music group were higher compared to the pop and religious music group. To improve this study, future similar study with a higher species is mandatory.

\section{REFERENCES}

Campbell D. (2003). The Mozart Effect for Parents: Unlocking the potential of your cbild. New York: Penguin publishers.

Chaudhury S., Nag TC., Jain S and Wadhwa S. (2013). Review: Role of Sound Stimulation in Reprogramming Brain Connectivity. J. Biosci. 38(3), 605-614

Ernawati, Hermanto TJ, Widjiati. (2008). Perbandingan Indeks Apoptosis Sel Otak Anak Tikus (Rattus norvegicus) Baru Labir Antara yang Mendapat Paparan Lagu Mozart Sejak. Awal Kebuntingan, 
Setelah Kebuntingan 10 Hari dan yang Tidak. Mendapat Paparan. Surabaya: Universitas Airlangga. Unpublished

Hepper P. (2007). Introduction of Infant Development. Second Edition. Oxford: University Press, P 4146

Hermanto. (2004). Smart babies through Prenatal University Mission Impossible. Majalah Obstetri dan Ginekologi Indonesia, 28(1):14.

Hermanto. (2013). Bersujud dalam Rabim 2, Mencerdaskan Janin Sejak Dalam Rabim dengan Kombinasi Stimulasi 11-14 Musik Karya Mozart dan Nutrisi. Surabaya: Global Persada Press.

Hill, M.A. (2015). Embryology Neural System - Glial Development. RetrievedApril 10, 2019, from https://embryology.med.unsw.edu.au/embryology/index.php/Neural_System__Glial_Development. [Accessed1 Februari 2019].

Houzel SH. (2014). The Glia/Neuron Ratio: How it Varies Uniformly Across Brain Structures and Species and What that Means for Brain Physiology and Evolution. Wiley Periodicals, Inc.

Ismudi H, Hermanto TJ, Widjiati. (2007). Perbandingan Indeks Apoptosis Sel Otak ANAK Tikus yang Mendapat Paparan Musik Mozart 1, Mozart II, Mozart III dan yang tidak mendapat paparan selama kebuntingan. Surabaya: Universitas Airlangga. Unpublished

Kim H, Lee MH, Chang HK and Lee TH. (2006). Influence of prenatal noise and music on the spatial memory and neurogenesis in the hippocampus of developing rats. Brain Dev., 28(2):109-14.

Mustajib, A. (2010). Rahasia Dabsyat Terapi Otak. Jakarta: PT. Wahyu Media.

Sanyal T., Palanisamy P, Nag TC., Roy TS. And Wadhwa S. (2013). Effect of Prenatal Loud Music and Noise on Total Number of Neurons and Glia, Neuronal Nuclear Area Volume of Chick Brainstem Auditory Nuclei, Field L and Hippocampus: A Stereological Investigation. Int. J. Devl Neuroscience 31. 234-244.

Sari NR. (2005). Musik dan Kecerdasan Otak Bayi. Bogor: Penerbit Kharisma Buta Aksara.

Singer E. (2004). Molecular Basis for Mozart Effect Relevealed. New Scientist.

United Nations Development Programme [UNDP]. (2018). Human Development Indices and Indicators 2018 Statistical Update. New York.

Verkhratsky, A. (2010). Physiology of Neuronal-glial Networking. Neurochemistry International, 57. 332-343

Whitwell, Giselle E. 2009. The Importance of Prenatal Sound and Music. The Journal of Prenatal \& Perinatal Psychology and Health.

Xing Y, Xia Y, Kendrick K, Liu X, Wang M, Wu D, Yang H, Jing W, Guo D, and Yao D. 2015. Mozart, Mozart Rhythm and Retrograde Mozart Effects: Evidences From Behaviours and Neurobiology Bases. Nature Scientific Reports, 1-11 